\title{
DRY MATTER AND MACRONUTRIENT ACCUMULATION IN FRUITS OF CONILON COFFEE WITH DIFFERENT RIPENING $\operatorname{CYCLES}^{(1)}$
}

\author{
Fábio Luiz Partelli ${ }^{(2)}$, Marcelo Curitiba Espindula ${ }^{(3)}$, Wellington Braida Marré(4) \& \\ Henrique Duarte Vieira ${ }^{(5)}$
}

\begin{abstract}
SUMMARY
The period between anthesis and fruit ripening varies according to the Conilon coffee (Coffea canephora) genotype. Therefore, the time of the nutritional requirements for fruit formation may differ, depending on the formation phase and the genotype, and may directly affect split application of fertilizer. The aim of this study was to quantify the accumulation of dry matter and $\mathrm{N}, \mathrm{P}, \mathrm{K}, \mathrm{Ca}, \mathrm{Mg}$ and $\mathrm{S}$ at several stages in the fruit of the Conilon coffee genotype with different ripening cycles, which may suggest the need for split application of fertilizer in coffee. The experiment was carried out in the municipality of Nova Venecia, Espírito Santo, Brazil, throughout the reproductive cycle. The treatments were composed of four coffee genotypes with different ripening cycles. A completely randomised experimental design was used. with five replicates. Plagiotropic branches were harvested from flowering to fruit ripening at 28-day intervals to determine the dry matter of the fruits and the concentration and accumulation of the nutrients they contained. The behavior of dry matter and macronutrient accumulation during the study period was similar and increasing, but it differed among genotypes sampled in the same season. Early genotypes exhibited a higher speed of dry matter and nutrient accumulation. Split application of fertilizer should differ among coffee genotypes with different ripening cycles (early, intermediate, late and very late).
\end{abstract}

Index terms: Coffea canephora, genotypes, maturation cycle, fertilization management.

(1) Received for publication on March 13, 2013 and approved on October 25, 2013.

(2) Adjunct Professor, Universidade Federal do Espírito Santo. Rod. BR 101 Norte, km 60, Bairro Litorâneo. CEP 29932-540 São Mateus (ES), Brazil. E-mail: partelli@yahoo.com.br

(3) Researcher at Embrapa Rondônia, BR 364, km 5.5. Caixa Postal 127. CEP 76815-800 Porto Velho (RO), Brazil. E-mail: marcelo.espindula@embrapa.br

(4) Researcher at Incaper. Av. Vitória, s/n. CEP 29830-000 Nova Venécia (ES), Brazil. E-mail: marre@incaper.es.gov.br

(5) Adjunct Professor, Universidade Estadual do Norte Fluminense Darcy Ribeiro, Centro de Ciências e Tecnologias Agropecuárias. Av. Alberto Lamego, 2000. Parque Califórnia. CEP 28013-600 Campos dos Goytacazes (RJ), Brazil. E-mail: henrique@uenf.br 


\title{
RESUMO: ACÚMULO DE MATÉRIA SECA E MACRONUTRIENTES EM FRUTOS DE CAFÉ CONILON COM DIFERENTES ÉPOCAS DE MATURAÇÃO
}

\begin{abstract}
O período compreendido entre a antese e a maturação dos frutos varia em razão do genótipo de café Conilon (Coffea canephora). Portanto, possivelmente a exigência nutricional para formação do fruto pode ser diferente, conforme a fase e o genótipo, influenciando diretamente no parcelamento da adubação. Objetivou-se quantificar, em diversas fases, a matéria seca e o acúmulo de $N, P, K, C a, M g$ e $S$ no fruto de genótipos de cafeeiro Conilon com distintos ciclos de maturação, podendo, assim, sugerir a necessidade de diferente parcelamento na adubação. O experimento foi conduzido no município de Nova Venécia, Espírito Santo, Brasil, durante todo o ciclo reprodutivo. Os tratamentos foram quatro genótipos de cafeeiro com ciclo de maturação diferenciado. O delineamento experimental foi o inteiramente casualizado com cinco repetições. A partir do florescimento até a maturação dos frutos, foram colhidos ramos plagiotrópicos, em intervalos de 28 dias, para determinação da matéria seca dos frutos e das concentrações e dos acúmulos de nutrientes desses. O acúmulo da matéria seca e dos macronutrientes ao longo do período avaliado foi similar e crescente; contudo, foi diferenciado entre os genótipos na mesma época de amostragem. Genótipos precoces apresentam maior velocidade de acúmulo da matéria seca e dos nutrientes avaliados. O parcelamento da adubação deve ser diferente entre os genótipos de cafeeiro com ciclo de maturação diferenciado (precoce, intermediário, tardio e supertardio).
\end{abstract}

Termos de indexação: Coffea canephora, genótipos, ciclo de maturação, manejo da adubação.

\section{INTRODUCTION}

The genus Coffea, which has more than 100 described species, contains three species that are grown commercially for beverage production: $C$. arabica, C. canephora and C. liberica (Davis et al., 2006). Although the species C. arabica is the most commonly grown species throughout the world, the cultivation of $C$. canephora has contributed significantly to increased world coffee production. In Brazil, out of the total of 50.8 million $60-\mathrm{kg}$ bags produced in 2012, $24.6 \%$ are C. canephora (CONAB, 2013).

Knowledge of the ripening periods of coffee fruit is critical for agricultural planning for the purpose of predicting harvest, quality and marketing (BardinCamparotto et al., 2012), including important studies on gene expression in different periods of fruit development (Budzinski et al., 2011). The term "maturation cycle" has been used to predict such periods and refers to the time between flowering and fruit ripening. Maturation cycles may vary depending on climatic conditions and/or the coffee genotype grown (Pezzopane et al., 2003; Petek et al., 2009).

Coffee plants of the species $C$. canephora reproduce by allogamy. Therefore, it is necessary to use asexual propagation for obtaining productive varieties with defined maturation cycles (Bragança et al., 2001). These varieties are polyclonal (Fonseca et al., 2004), i.e., they are formed by sets of genotypes that are generally grouped according to their maturation cycle: early, intermediate, late and very late.

In addition to cycle differentiation, the length of each stage of the cycle is also variable (Laviola et al.,
2008) and may affect dry matter and nutrient accumulation rates in fruits (Laviola et al., 2007a,b). In addition, the period of fruit formation coincides with the period of higher vegetative growth, i.e., when there is increased requirement for nutrients, which is from September to May in the State of Espírito Santo (Partelli et al., 2010, 2013). Thus, knowledge of the dynamics of fruit formation is important for recognition of periods of increased nutritional demands and definition of the best strategies for crop fertilization.

Considering the lack of information in the literature, the aim of this study was to establish dry matter and macronutrient accumulation curves in fruits of 'Conilon' coffee plants with distinct maturation cycles (early, intermediate, late and very late).

\section{MATERIALS AND METHODS}

The experiment was conducted on a property located in the municipality of Nova Venécia in the state of Espírito Santo. The area is located at approximately $18^{\circ} 43^{\prime} 46^{\prime \prime} \mathrm{S}, 40^{\circ} 23^{\prime} 10^{\prime \prime} \mathrm{W}$, with an average elevation of $100 \mathrm{~m}$ asl. In low areas of the municipality, the average minimum temperature ranges from 11.8 to $18{ }^{\circ} \mathrm{C}$, and the maximum temperature ranges from 30.7 to $34{ }^{\circ} \mathrm{C}$. The rainfall rate is approximately $1,200 \mathrm{~mm}$ per year (Incaper, 2013). During the experiment, the crop was properly irrigated and underwent no water deficit.

Three-year-old C. canephora Conilon plants were used, which were grown under full sun with a spacing 
of $3 \mathrm{~m}$ between rows and $1 \mathrm{~m}$ between plants, with four orthotropic stems per plant. The soil was classified as a cohesive Dystrophic Red-Yellow Latossol (Oxisol) (Embrapa, 2006), clayey, on rolling land with the following properties in the $0.0-0.20 \mathrm{~m}$ layer: soil organic mater $(\mathrm{SOM})=1.95 \mathrm{dag} \mathrm{kg}^{-1}$, $\mathrm{pH}\left(\mathrm{H}_{2} \mathrm{O}\right)=5.41, \mathrm{P}=6.1 \mathrm{mg} \mathrm{dm}^{-3}, \mathrm{~K}=66 \mathrm{mg} \mathrm{dm}^{-3}$, $\mathrm{Ca}=1.35 \mathrm{cmol}_{\mathrm{c}} \mathrm{dm}^{-3}, \mathrm{Mg}=0.78 \mathrm{cmol}_{\mathrm{c}} \mathrm{dm}^{-3}, \mathrm{~S}_{-} \mathrm{SO}_{4}=$ $7.0 \mathrm{mg} \mathrm{dm}^{-3}, \mathrm{~B}=0.2 \mathrm{mg} \mathrm{dm}^{-3}, \mathrm{Cu}=0.4 \mathrm{mg} \mathrm{dm}^{-3}$, $\mathrm{Fe}=36.8 \mathrm{mg} \mathrm{dm}^{-3}, \mathrm{Mn}=21.0 \mathrm{mg} \mathrm{dm}^{-3}$ and $\mathrm{Zn}=$ $3.2 \mathrm{mg} \mathrm{dm}^{-3}$. During the experiment, the plants were managed according to the technical recommendations for the crop. Soil fertilization was performed through the application of $110 \mathrm{~g}$ of simple superphosphate and $80 \mathrm{~g}$ of the 20-00-20 formulate in November and December 2010, respectively, and $100 \mathrm{~g}$ and $120 \mathrm{~g}$ of 20-00-20 per plant in March and May 2011, respectively.

The treatments were composed of four genotypes (clones) of coffee trees with different maturation cycles (early, intermediate, late and very late). The genotypes selected were clones $12 \mathrm{~V}, 10 \mathrm{~V}$ and $13 \mathrm{~V}$ from the variety Conilon, Vitória 8142 and Ipiranga 501. A completely randomized experimental design was used with five replicates (five plants). Initially, 70 plagiotropic branches with the same pattern per genotype were marked at random. The experimental plot consisted of one plant from which one plagiotropic branch was extracted every 28 days, from flowering until fruit ripening, to determine the dry matter and the concentrations and accumulations of $\mathrm{N}, \mathrm{P}, \mathrm{K}, \mathrm{Ca}, \mathrm{Mg}$ and $\mathrm{S}$ in the fruits. The branches had, on average, 13 rosettes with coffee fruits.

Sampling began on August 14, 2010, 20 days after anthesis for the early and intermediate genotypes $(12 \mathrm{~V}$ and 10V), and on September 11, 2010 for the late and very-late genotypes (13V and Ipiranga 501). Sixty-five uniform plagiotropic branches per genotype were previously and randomly marked. Five branches were removed/sampled at random every 28 days. The sampling finished on March 6, April 8, May 7 and July 3,2011 , in the early, intermediate, late and very late genotypes, respectively.

The fruits were extracted and dried in a greenhouse with forced air circulation at $70{ }^{\circ} \mathrm{C}$ until constant mass was obtained. Their dry matter was then determined on a $0.001 \mathrm{~g}$ precision scale. The fruits were ground in a stainless steel Willey mill and sieved in a $0.841 \mathrm{~mm}$ mesh sieve for chemical analyses of $\mathrm{N}$, $\mathrm{P}, \mathrm{K}, \mathrm{Ca}, \mathrm{Mg}$ and $\mathrm{S}$. The analyses were performed in a laboratory using the method described by Silva (1999), in triplicate.

The accumulation of nutrients in the fruits present on the branches was calculated considering the dry matter and the concentration of the respective nutrients. The percentage of accumulation at different seasons was then calculated, and the last collection was considered $100 \%$, in which more than $80 \%$ of the fruits on the branches were fully ripe.
The data were subjected to regression analysis, and the mathematical models were chosen in accordance with the equations with the best fit, corroborated by the higher values for the coefficients of determination $\left(\mathrm{R}^{2}\right)$ and by the significance of the regression coefficients and the regression $\mathrm{F}$ test $(\leq 0.05)$. The tables show the averages and the standard error of the average.

\section{RESULTS AND DISCUSSION}

The four genotypes (clones) of 'Conilon' coffee showed similar dry matter accumulation curves in fruits (Figure 1). In all cases, the period of fruit formation presented sigmoidal behavior - an initial stage with less expressive accumulation rates, followed by a stage of rapid expansion and the highest rates, and a final stage with less expressive rates at the end of the cycle of fruit formation. This behavior is similar to that observed in arabica coffee plants (Laviola et al., 2007a, 2008), whose trend curves showed sigmoidal behavior. It was possible to identify five different stages of fruit formation, namely, fruitlets, rapid expansion, suspended growth and graining (or grain filling), which are related to this growth model. The highest accumulation rates are found in the stages of rapid expansion, suspended growth and grain filling.

Recent surveys indicate similar results regarding nutrient accumulation for potato (Fernandes et al., 2011) and cotton (Rosolem et al., 2012) crops, which reinforces the practical relevance of this information for various crops as the information is directly associated with plant nutrient requirements and the consequent need for split application of fertilizer.

Although the genotypes presented similar behavior for accumulation rates, the duration of each stage differed, and this resulted in a 216 -day cycle for the early genotype, a 244-day cycle for the intermediate and late genotypes, and a 300-day cycle for the very late genotype. It is noteworthy that although the intermediate genotype presented cycle duration similar to the late genotype, the latter was harvested afterwards because its primary flowering occurred 30 days after the former.

Nitrogen accumulation in the fruits of the early and intermediate genotypes followed a trend similar to dry matter accumulation, with sigmoidal behavior. In contrast, the late and very late genotypes did not follow the same pattern of dry matter accumulation and showed exponential curves (Figure 2). The behaviors of the early and intermediate genotypes are similar to the results observed for genotypes of $C$. arabica at different altitudes (Laviola et al., 2008), which indicates that the formation of fruits is similar 


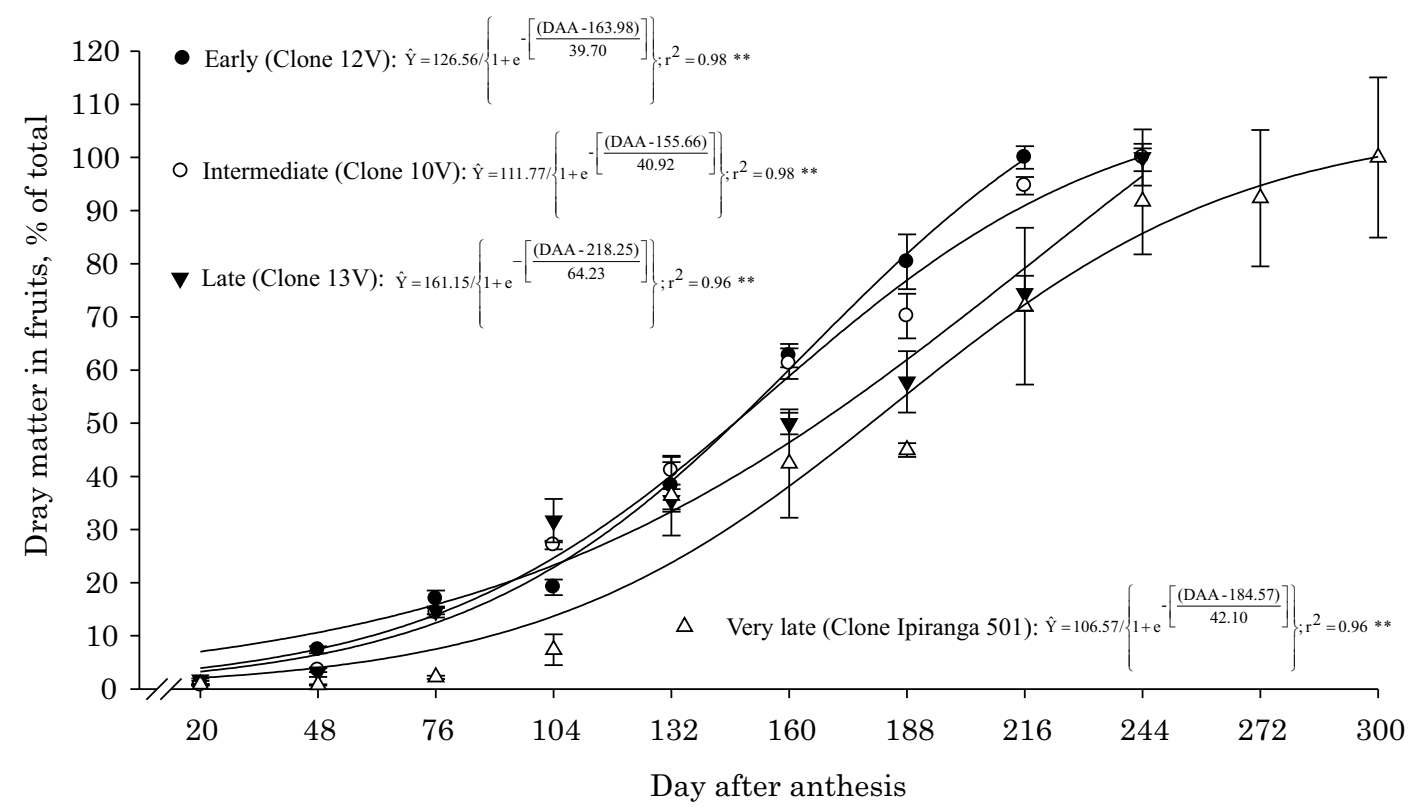

Figure 1. Dry matter accumulation in fruits (as a percentage of the cumulative total) of four genotypes (clones) of Conilon coffee, from anthesis to fruit maturation. The bars refer to the standard error of the average. ** significant at $1 \%$ probability.

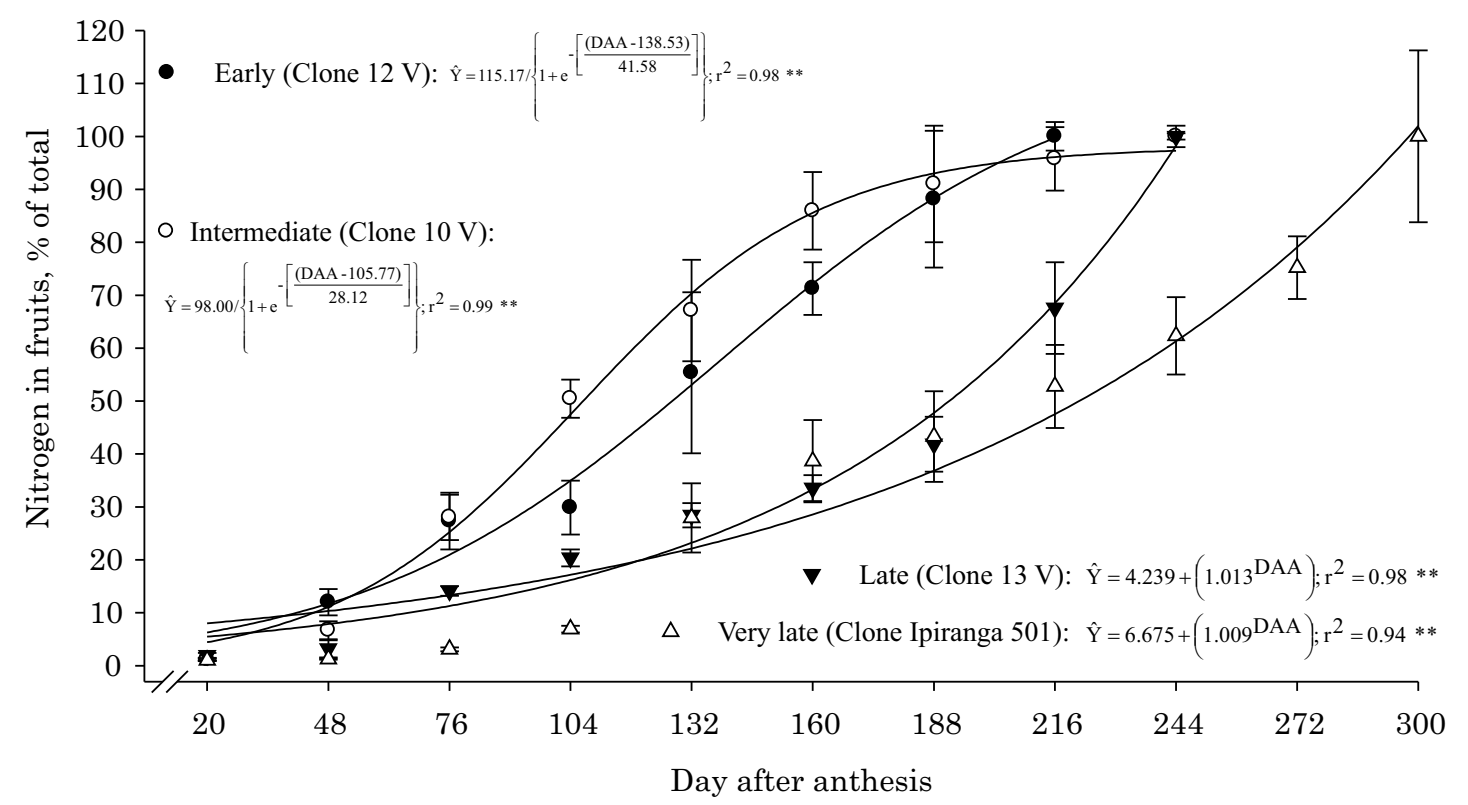

Figure 2. Accumulation of nitrogen in fruits (in percentage of the cumulative total) of four genotypes (clones) of Conilon coffee, from anthesis to fruit maturation. The bars refer to the standard error of the average. ** significant at $1 \%$ probability.

for both genotypes. However, the behaviors of the late and very late genotypes suggest that there are differences within the same species that should be considered in the nutritional management of plants of these crops. Thus, it is suggested that split application of fertilizer should be different depending on the genotype.

In practice, at the time of nitrogen fertilization on March 12, 2011, the fruits at 222 (early and intermediate) and 194 (late and very late) days of formation presented 100, 96, 52 and $38 \%$ of the total accumulated $\mathrm{N}$ for the early, intermediate, late and very late genotypes, respectively. Considering these accumulations, it is assumed that there is difference in $\mathrm{N}$ demand from genotypes in this period. Therefore, different fertilization practices should be applied to the genotypes studied. 
Therefore, the fertilization on May 30 should also be modified because the early, intermediate and late genotypes had been harvested while the very late genotype presented fruits at 267 days of development, with $73 \%$ of the total accumulated N. Moreover, the genotypes studied may have different efficiencies of nutrient use, as observed in Arabica coffee (Amaral et al., 2011). Such traits deserve further study and should be considered in the establishment of a fertilization strategy for precision agriculture.

Early, intermediate and late genotypes showed the same behavior for accumulation of $\mathrm{P}, \mathrm{K}, \mathrm{Ca}, \mathrm{Mg}$ and $\mathrm{S}$, with sigmoid trend curves. In contrast, the very late genotype showed the same trend only for the accumulation of $\mathrm{Ca}$ and $\mathrm{S}$, while the accumulation of $\mathrm{P}, \mathrm{K}$ and $\mathrm{Mg}$ showed an exponential behavior. Even with similar behavior, the very late genotype presented curves that were different from the other genotypes in the accumulation of all the nutrients studied (Figures 3, 4, 5, 6 and 7).

Genotypes with a shorter fruit ripening cycle have a higher rate of accumulation of dry matter, N, P, K, $\mathrm{Ca}, \mathrm{Mg}$ and $\mathrm{S}$ (Figures 1-7). Previous research on Conilon coffee conducted by Morais et al. (2012) suggests that the early maturation of some genotypes may be associated with a higher rate of net photosynthesis and greater stomatal opening since these traits were quantified in the early genotype, followed by the intermediate and late genotypes, in two out of the three seasons evaluated (September and January).

Discrepancy in the late genotype is related to genetic differences between the varieties studied since the early, intermediate and late genotypes are the genotypes $12 \mathrm{~V}, 10 \mathrm{~V}$ and $13 \mathrm{~V}$, respectively, of the variety 'Conilon Vitória-Incaper 8142' (Fonseca et al., 2004) while the late genotype is 'Ipiranga 501', a component of the homonymous variety. This difference suggests that fertilizer management should be specific for each variety.

The $\mathrm{P}$ accumulation curves were similar to those found in varieties of $C$. arabica grown in the forest zone of Brazil (Laviola et al., 2009) in a study where no $\mathrm{P}_{2} \mathrm{O}_{5}$ was applied due to the satisfactory levels of this nutrient in the soil. Some studies have indicated that a severe water deficit leads to decreased foliar concentration of $\mathrm{P}$ in arabica coffee (Worku \& Astatkie, 2010) and may also impair the metabolism of coffee plants (Santos et al., 2011; Marraccini et al., 2012). However, that was not observed in this study as the crop was properly irrigated.

Regarding split application of potassium fertilization, the results found in C. arabica 'Caturra' suggest two absorption peaks, with approximately $50 \%$ of K accumulated between 60 and 120 days after flowering and $20 \%$ between 210 and 240 days (Ramírez et al., 2002). These peaks are related to the stages of rapid growth and maturation. Thus, as genotypes have different cycles, the supply of $\mathrm{K}_{2} \mathrm{O}$ should be performed in accordance with the increase of the $\mathrm{K}$, requirement which is specific to each genotype. Ramírez et al. (2002) also described the accumulation of $45 \%$ of $\mathrm{N}$ between 60 and 90 days after flowering and $15 \%$ between 210 and 240 days, which demonstrates that $\mathrm{K}$ should be applied together with $\mathrm{N}$.

In accordance with the $\mathrm{Ca}$ accumulation curves, $70 \%$ of the Ca in the fruits of the early, intermediate, late and very late genotypes was accumulated up to 160, 170, 140 and 230 days after anthesis. The early

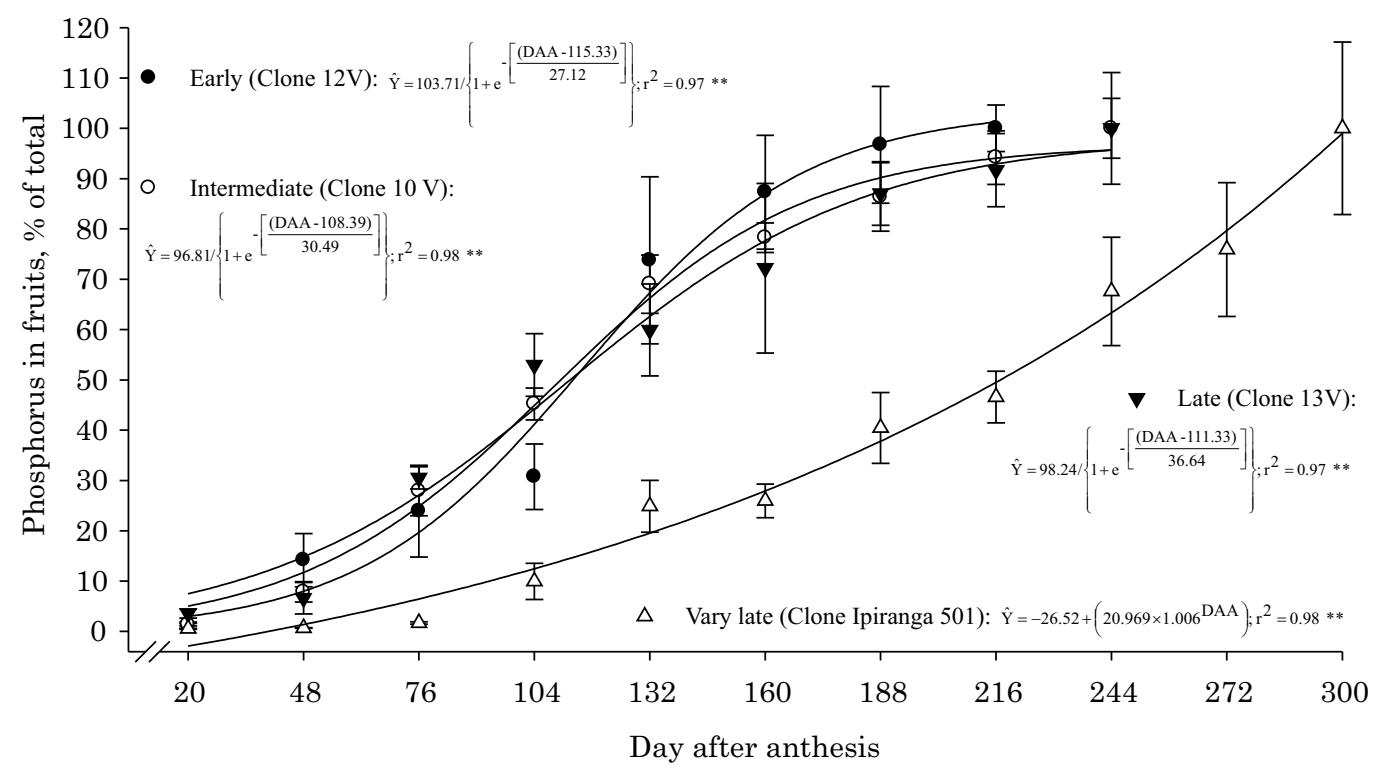

Figure 3. Accumulation of phosphorus in fruits (in percentage of the cumulative total) of four genotypes (clones) of Conilon coffee, from anthesis to fruit maturation. The bars refer to the standard error of the average. ** significant at $1 \%$ probability. 


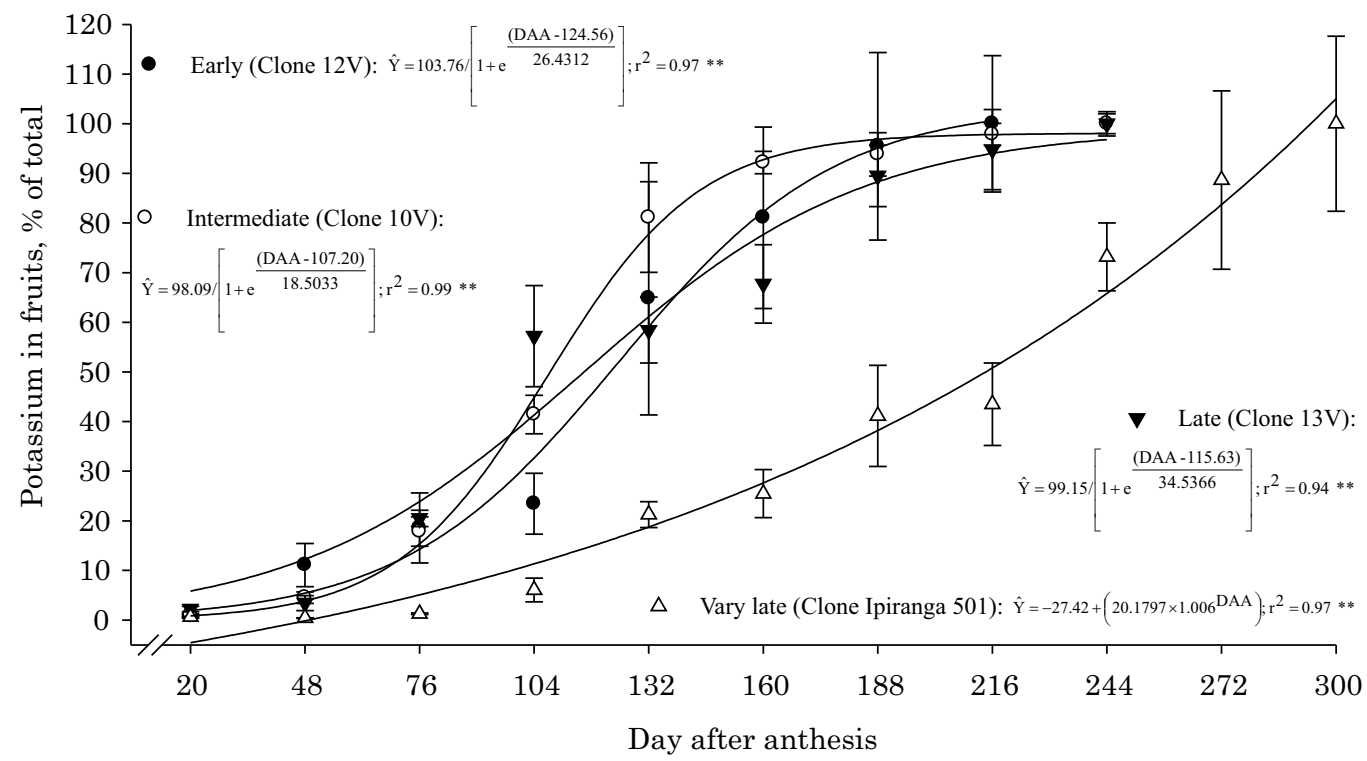

Figure 4. Accumulation of potassium in fruits (in percentage of the cumulative total) of four genotypes (clones) of Conilon coffee, from anthesis to fruit maturation. The bars refer to the standard error of the average. ** significant at $1 \%$ probability.

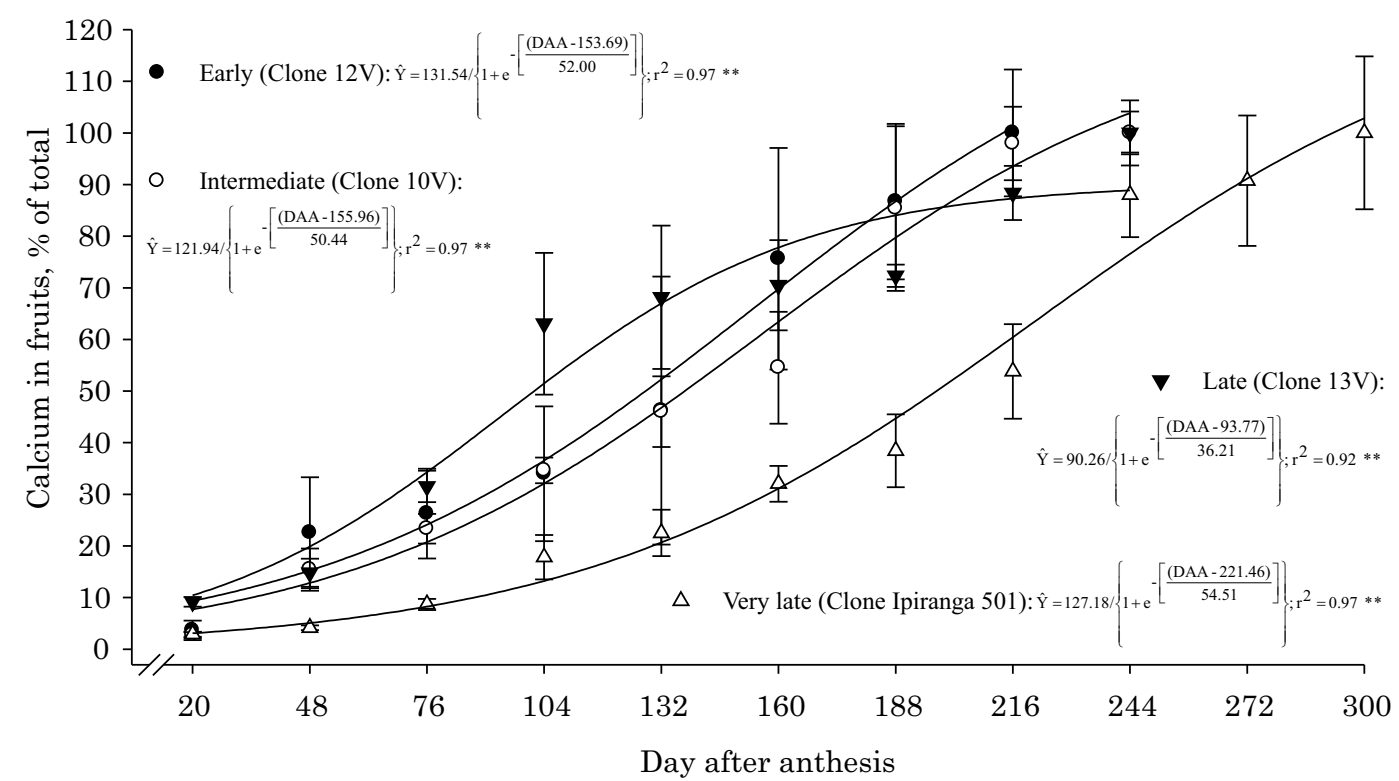

Figure 5. Accumulation of calcium in fruits (in percentage of the cumulative total) of four genotypes (clones) of Conilon coffee, from anthesis to fruit maturation. The bars refer to the standard error of the average. ** significant at $1 \%$ probability.

accumulation in the first three genotypes is similar to that reported for C. arabica Caturra in which $70 \%$ was accumulated by 120 days (genotype with maturation cycle of 240 days) (Ramirez et al., 2002). Moreover, the behavior of the very-late genotype shows differences in the duration of the stages of fruit development since the highest rates of accumulation of $\mathrm{Ca}$ are related to cell wall formation and stabilization of membranes and occur at stages of rapid extension and suspended growth.
$\mathrm{Ca}$ is the second nutrient that is most accumulated by 'Conilon' coffee trees (Bragança et al., 2008) and, like $\mathrm{Mg}$, it is usually provided by liming. However, Ramírez et al. (2002) suggest foliar application of calcium-based fertilizers at the time of higher requirement, to supply this high demand. Similarly, the early, intermediate, late and very-late genotypes accumulated $70 \%$ of $\mathrm{Mg}$ in fruits up to 140, 155, 175 and 268 days, respectively. 


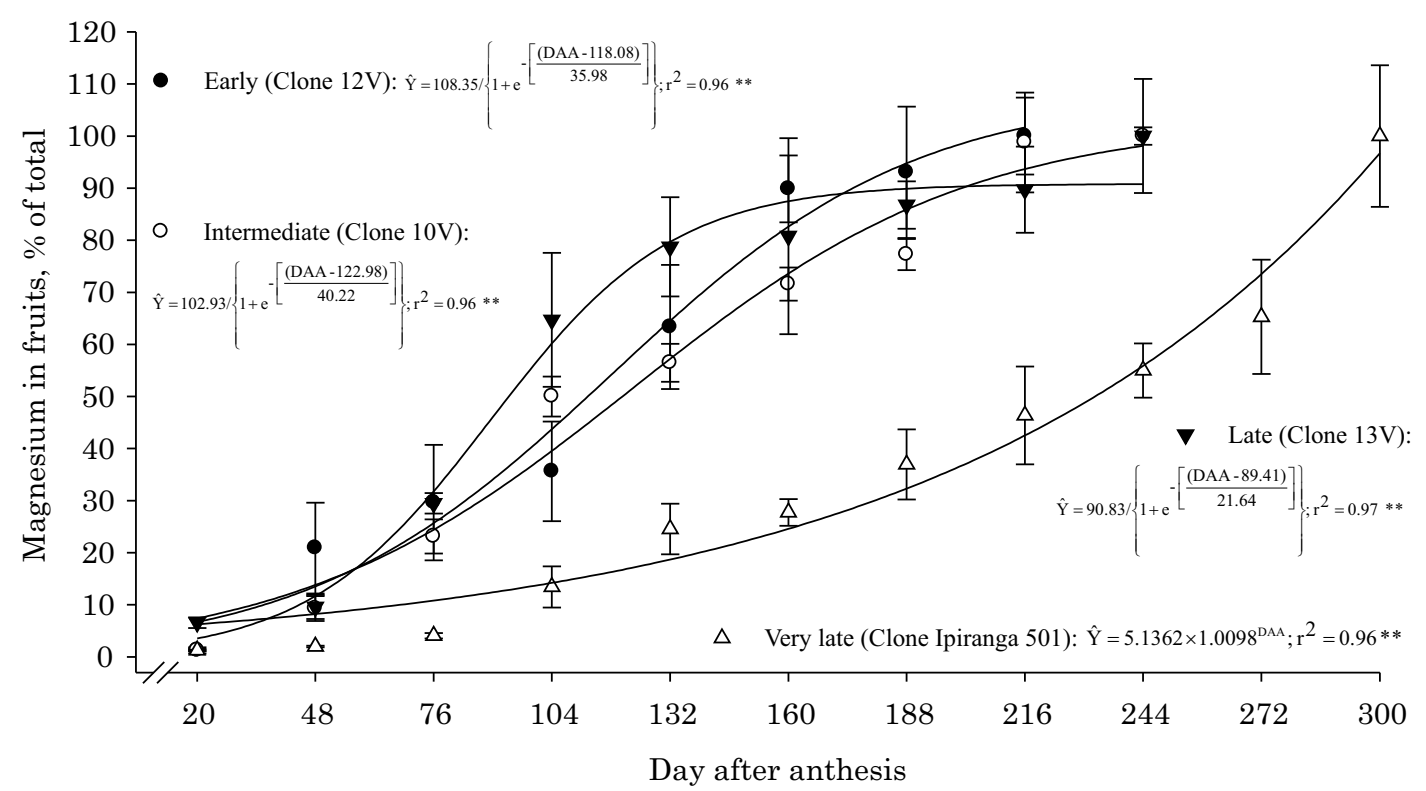

Figure 6. Accumulation of magnesium in fruits (in percentage of the cumulative total) of four genotypes (clones) of Conilon coffee, from anthesis to fruit maturation. The bars refer to the standard error of the average. ** significant at $1 \%$ probability.

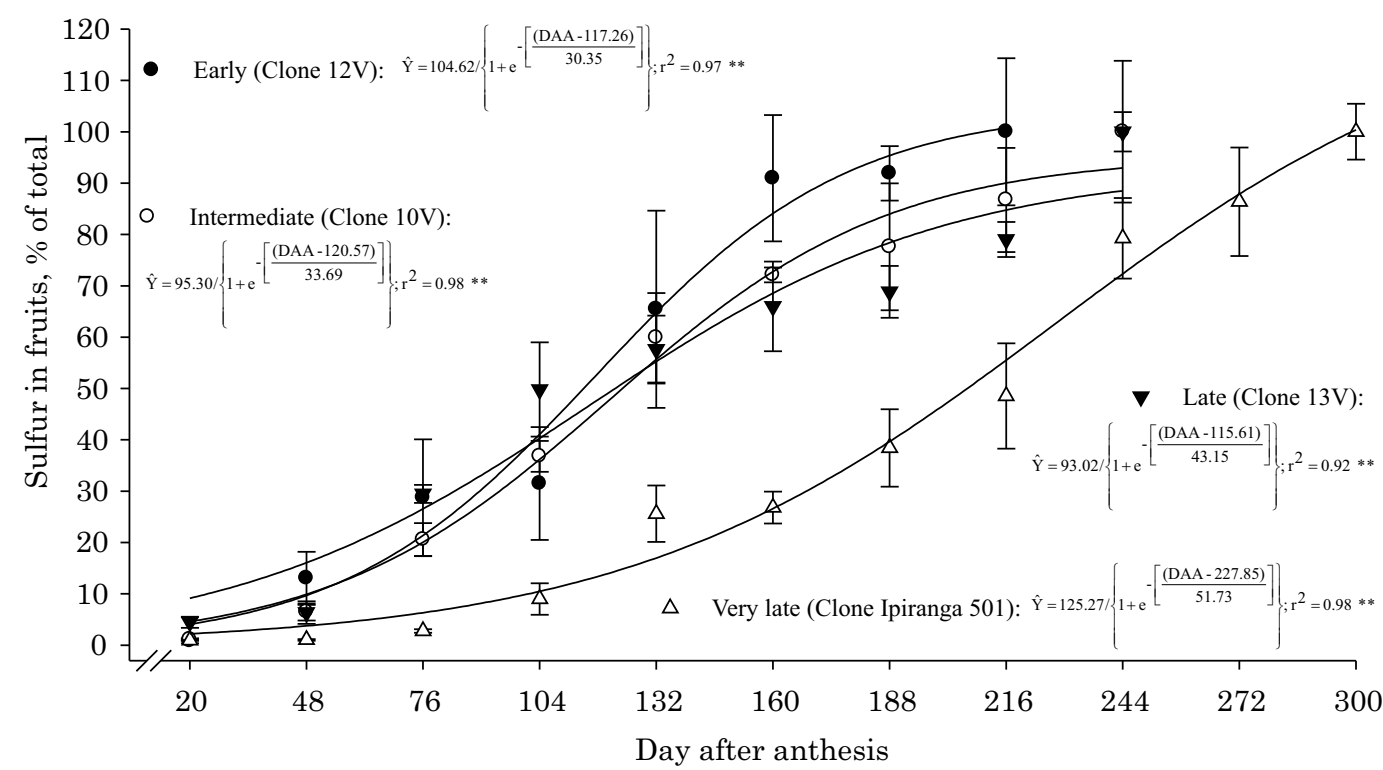

Figure 7. Accumulation of sulphur in fruits (in percentage of the cumulative total) of four genotypes (clones) of Conilon coffee, from anthesis to fruit maturation. The bars refer to the standard error of the average. ** significant at $1 \%$ probability.

Sulphur was sigmoidally accumulated, and the highest rates were observed at the early stages of fruit formation. This behavior was similar to that reported for C. arabica Caturra, for which more than $43 \%$ of S was accumulated from 60 to 90 days after anthesis (Ramírez et al., 2002), which corresponds to the of rapid expansion stage. However, the varieties IAC99, Rubi MG-1192 and Acaiá IAC-474-19, under the conditions of the Brazilian Zona da Mata, showed two $S$ absorption peaks: the first, at the stage of rapid expansion; and the second, at the stage of grain filling and ripening (Laviola et al., 2009). The second stage is associated with protein synthesis in seeds, and its absence in the genotypes of C. canephora studied may be due to genetic factors, growing conditions or the interval between grain collections. 


\section{CONCLUSIONS}

1. Genotypes $12 \mathrm{~V}, 10 \mathrm{~V}$ and $13 \mathrm{~V}$ have similar curves of accumulation of dry matter, $\mathrm{N}, \mathrm{P}, \mathrm{K}, \mathrm{Ca}$, $\mathrm{Mg}$ and $\mathrm{S}$, but genotype Ipiranga 501 differs from them.

2. Genotypes with a shorter fruit ripening cycle have a higher rate of accumulation of dry matter and nutrients.

3. Fertilization management of genotypes $12 \mathrm{~V}$, $10 \mathrm{~V}, 13 \mathrm{~V}$ and Ipiranga 501 should be different in accordance with the length of the cycle so as to supply plants at times of higher nutrient need.

\section{ACKNOWLEDGMENTS}

The authors thank the Universidade Federal do Espírito Santo for support of this research, the farmer João Batista Marré for making the study area available, and Fertilizantes Heringer for the support provided.

\section{LITERATURE CITED}

AMARAL, J.F.T.; MARTINEZ, H.E.P.; LAVIOLA, B.G.; FERNANDES FILHO, E.I. \& CRUZ, C.D. Eficiência de utilização de nutrientes por cultivares de cafeeiro. Ci. Rural, 41:621-629, 2011

BARDIN-CAMPAROTTO, L.; CAMARGO, M.B.P. \& MORAES, J.F.L. Época provável de maturação para diferentes cultivares de café arábica para o Estado de São Paulo. Ci. Rural, 42:594-599, 2012.

BRAGANÇA, S.M.; CARVALHO, C.H.S.; FONSECA, A.F.A. \& FERRÃO, R.G. Variedades clonais de café Conilon para o Estado do Espírito Santo. Pesq. Agropec. Bras., 36:765$770,2001$.

BRAGANÇA, S.M.; MARTINEZ, H.E.P.; LEITE, H.G.; SANTOS, R.P.; SEDIYAMA, C.S.; ALVAREZ V., V.H. \& LANI, J.L. Accumulation of macronutrients for the Conilon coffee tree. J. Plant Nutr., 31:103-120, 2008.

BUDZINSKI, I.G.F.; SANTOS, T.B.; SERA, T.; POT, D.; VIEIRA, L.G.E. \& PEREIRA, L.F.P. Expression patterns of three a-expansin isoforms in Coffea arabica during fruit development. Plant Biol., 13:462-471, 2011.

COMPANHIA NACIONAL DE ABASTECIMENTO - CONAB. Acompanhamento de safra brasileira: Café: Safra 2013, primeira estimativa, janeiro de 2013. Available at: <http:/ /www.conab.gov.br/conteudos.php?a=1253\&t=>. Accessed: Jan. 22, 2013.

DAVIS, A.P.; GOVAERTS, R.; BRIDSON, D.M. \& STOFFELEN, P. An annotated taxonomic conspectus of the genus Coffea (Rubiaceae). Bot. J. Linn. Soc., 152:465-512, 2006.
EMPRESA BRASILEIRA DE PESQUISA AGROPECUÁRIA . EMBRAPA. Centro Nacional de Pesquisa de Solos. Sistema brasileiro de classificação de solos. Rio de Janeiro: Embrapa-SPI, 2006. 306p.

FERNANDES, A.M.; SORATTO, R.P. \& SILVA, B.L. Extração e exportação de nutrientes em cultivares de batata. I - Macronutrientes. R. Bras. Ci. Solo, 35:20392056, 2011.

FONSECA, A.F.A.; FERRÃO, M.A.G.; FERRÃO, R.G.; VERDIN-FILHO, A.C.; VOLPI, P.S. \& ZUCATELI, F. 'Conilon Vitória - Incaper 8142': improved Coffea canefora var. kouillou clone cultivar for the State of Espírito Santo. Crop Breed Appl. Biot., 4:503-505, 2004.

INSTITUTO CAPIXABA DE PESQUISA, ASSISTÊNCIA TÉCNICA E EXTENSÃO RURAL - INCAPER. Caracterização climáticas dos municípios: Nova Venécia. Available at: <http:// hidrometeorologia.incaper.es.gov.br/caracterizacao/ novavenecia_carac.php>. Accessed: Mar. 08, 2013.

LAVIOLA, B.G.; MARTINEZ, H.E.P.; SOUZA, R.B.; SALOMÃO, L.C.C. \& CRUZ, C.D. Macronutrient accumulation in coffee fruits at Brazilian Zona da Mata conditions. J. Plant Nutr., 32:980-995, 2009

LAVIOLA, B.G.; MARTINEZ, H.E.P.; SALOMÃO, L.C.C.; CRUZ, C.D.; MENDONÇA, S.M. \& ROSADO, L. Acúmulo em frutos e variação na concentração foliar de NPK em cafeeiro cultivado em quatro altitudes. Biosci. J., 24:19-31, 2008.

LAVIOLA, B.G.; MARTINEZ, H.E.P.; SALOMÃO, L.C.C.; CRUZ, C.D. \& MENDONÇA, S.M. Acúmulo de nutrientes em frutos de cafeeiro em quatro altitudes de cultivo: Cálcio,magnésio e enxofre. R. Bras. Ci. Solo, 31:1451-1462, 2007a.

LAVIOLA, B.G.; MARTINEZ, H.E.P.; SALOMÃO, L.C.C.; CRUZ, C.D.; MENDONÇA, S.M. \& ROSADO, L.D.S. Acúmulo de nutrientes em frutos de cafeeiro em duas altitudes de cultivo: Micronutrientes. R. Bras. Ci. Solo, 31:1439-1449, 2007b.

MARRACCINI, P.; VINECKY, F.; ALVES, G.S.C.; RAMOS, H.J.O.; ELBELT, S.; VIEIRA, N.G.; CARNEIRO, F.A.; SUJII, P.S.; ALEKCEVETCH, G.C.; SILVA, V.A.; DAMATTA, F.M.; FERRÃO, M.A.; LEROY, T.; POT, D.; VIEIRA, L.G.E.; SILVA, F.R. \& ANDRADE, A.C. Differentially expressed genes and protein sup on drought acclimation in tolerant and sensitive genotypes of Coffea canephora. J. Exp. Bot., 63:4191-4212, 2012.

MORAIS, L.E.; CAVATTE, P.C.; DETMANN, K.C.; SANGLARD, L.M.V.P.; RONCHI, C.P. \& DAMATTA, F.M. Source strength increases with the increasing precociousness of fruit maturation in ûeld-grown clones of conilon coffee (Coffea canephora) trees. Trees, 26:1397-1402, 2012 .

PARTELLI, F.L.; VIEIRA, H.D.; SILVA, M.G. \& RAMALHO, J.C. Crescimento vegetativo sazonal em ramos de diferentes idades do cafeeiro conilon. Semina: Ci. Agric., 31:619-626, 2010 . 
PARTELLI, F.L.; MARRÉ, W.B.; FALQUETO, A.R.; VIEIRA, H.D. \& CAVATTI, P.C. Seasonal Vegetative growth in genotypes of Coffea canephora, as related to climatic factors. J. Agric. Sci., 5:108-116, 2013.

PETEK, M.R.; SERA, T. \& FONSECA, I.C.B. Exigências climáticas para o desenvolvimento e maturação dos frutos de cultivares de Coffea arabica. Bragantia, 68:169-181, 2009.

PEZZOPANE, J.R.M.; PEDRO JÚNIOR, M.J.; THOMAZIELLO, R.A. \& CAMARGO, M.B.P. Escala para avaliação de estádios fenológicos do cafeeiro arábica. Bragantia, 62:499-505, 2003.

RAMÍREZ, F.; BERTSCH, F. \& MORA, L. Consumo de nutrimentos por los frutos y bandolas de café caturra durante un ciclo de desarrollo y maduracion en aquiares, Turrialba, Costa Rica. Agron. Costarricense, 26:33-42, 2002.
ROSOLEM, C.A.; ECHER, F.R.; LISBOA, I.P. \& BARBOSA, T.S. Acúmulo de nitrogênio, fósforo e potássio pelo algodoeiro sob irrigação cultivado em sistemas convencional e adensado. R. Bras. Ci. Solo, 36:457-466, 2012.

SANTOS, T.B.; BUDZINSKI, I.G.F.; MARUR, C.J.; PETKOWICZ, C.L.O.; PEREIRA, L.F.P. \& VIEIRA, L.G.E. Expression of three galactinol synthase isoforms in Coffea arabica L. and accumulation of rafûnose and stachyose in response to abiotic stresses. Plant Physiol. Biochem., 49:441-448, 2011.

SILVA, F.C., org. Manual de análises químicas de solos, plantas e fertilizantes. Brasília, Empresa Brasileira de Pesquisa Agropecuária, 1999. 370p.

WORKU, M. \& ASTATKIE, T. Dry matter partitioning and physiological responses of Coffea arabica varieties to soil moisture deficit stress at the seedling stage in Southwest Ethiopia. African J. Agron. Res., 5:2066-2072, 2010. 